\title{
DETERMINAN PERSALINAN SESAR WANITA TANPA KOMPLIKASI KEHAMILAN DI INDONESIA 2017
}

\author{
(DETERMINANTS OF CESAREAN SECTION ON WOMAN WITHOUT PREGNANCY \\ COMPLICATION IN INDONESIA 2017)
}

Aditya Yogatama' ${ }^{1}$, Winih Budiarti²

(Politeknik Statistika STIS ${ }^{1}$ )

(Politeknik Statistika STIS²)

e-mail: 1 15.8459@stis.ac.id, 1 winih@stis.ac.id

\begin{abstract}
ABSTRAK
Tujuan nomor 3 Sustainable Development Goals (SDGS) adalah memastikan kehidupan yang sehat dan meningkatkan kesejahteraan untuk semua usia. Beberapa target dari tujuan tersebut adalah menurunkan angka kematian ibu pada tahun 2030 menjadi tidak lebih dari 70 per 100.000 kelahiran hidup dan mencapai cakupan kesehatan universal. Salah satu cara menurunkan risiko kematian pada ibu yang punya komplikasi kehamilan adalah secara normal adalah operasi sesar meskipun bukan berarti operasi sesar tidak memiliki efek samping. World Health Organization berpendapat bahwa angka persalinan sesar suatu negara diatas 10 persen tidak ada hubungannya dengan angka kematian ibu, kondisi ini belum terpenuhi di Indonesia pada tahun 2017 dimana angka persalinan sesar menyentuh angka 17 persen. Persalinan sesar juga lebih sering terjadi pada wanita perkotaan dimana sebesar 66,5 persen persalinan sesar dilakukan di perkotaan. Tidak hanya itu, hanya sebesar 25 persen wanita miskin yang memanfaatkan fasilitas ini. Meskipun angka persalinan sesar sudah terlalu tinggi, persalinan sesar lebih sering dimanfaatkan oleh golongan tertentu. Penelitian ini berjenis cross section menggunakan regresi logistik multilevel dengan tujuan menemukan gambaran umum dan karakteristik persalinan wanita tanpa komplikasi kehamilan dan variabel individual serta kontekstual yang mempengaruhinya. Hasil penelitian menunjukkan bahwa 13,8 persen persalinan wanita tanpa komplikasi kehamilan dilakukan secara sesar. Dari hasil analisis ditemukan bahwa 7,52 persen keragaman disebabkan oleh variabel kontekstual. Variabel-variabel yang berpengaruh secara signifikan adalah usia, pendidikan formal yang ditamatkan, riwayat keguguran, anak yang pernah dilahirkan dan karakteristik wilayah pdrb per kapita dan persentase rumah sakit swasta.
\end{abstract}

Kata kunci-persalinan sesar, komplikasi kehamilan, regresi logistik biner, multilevel

\section{ABSTRACT}

Goal number 3 of Sustainable Development Goals (SDGS) is to ensure a healthy life and improve well-being for all ages. Some of these goals are to reduce maternal mortality by 2030 to no more than 70 per 100,000 live births and reach universal universal health coverage. One way to reduce the risk of death in women who have complications of pregnancy is normal cesarean section although it does not mean cesarean section has no side effects. The World Health Organization believes that a country's cesarean birth rate above 10 percent has nothing to do with maternal mortality, this condition has not been fulfilled in Indonesia in 2017 where the number of cesarean births touched 17 percent. Cesarean delivery is also more common in urban women where 66.5 percent of cesarean deliveries are performed in urban areas. Not only that, only 25 percent of poor women use this facility. Although the rate of cesarean delivery is too high, cesarean delivery is more often utilized 
by certain groups. This research is a cross section type using multilevel logistic regression with the aim of finding a general description and characteristics of female deliveries without pregnancy complications and the individual and contextual variables that influence it. The results showed that 13.8 percent of female deliveries without pregnancy complications were performed by cesarean section. From the analysis it was found that 7.52 percent of diversity was caused by contextual variables. Variables that significantly influence are age, formal education completed, history of miscarriage, children ever born, GDP per capita and percentage of private hospitals.

\section{Keywords-Caesarean section, pregnancy complication, binary logistic regression, multilevel}

\section{PENDAHULUAN}

Salah satu tujuan Sustainable Development Goals(SDGs) adalah mengenai penurunan angka kematian ibu yaitu mencapai 70 per 100.000 kelahiran hidup pada tahun 2030. Salah satu cara ibu dengan komplikasi kehamilan agar bisa melahirkan adalah dengan persalinan sesar. Persalinan sesar adalah prosedur pembedahan untuk mengeluarkan bayi melalui irisan pada dinding abdomen dan rahim. Persalinan sesar memiliki beberapa keunggulan dibanding persalinan normal, yakni dapat dilakukan ketika ibu memiliki kondisi medis yang tidak memungkinkan, anak yang akan dilahirkan kembar, ukuran bayi besar sedangkan pinggul ibu kecil, bayi dalam keadaan sungsang, dan orang tua bisa memilih tanggal lahir bayi. Salah satu alasan wanita memilih persalinan sesar antara lain untuk menghindari rasa sakit (Cunningham dkk., 2014). Namun, bukan berarti operasi sesar tidak memiliki kelemahan. Souza (2013) mengategorikan risiko-risiko yang akan diakibatkan oleh persalinan sesar yaitu:

1. Dampak langsung, seperti infeksi, pendarahan, cedera, risiko obat bius, hingga kematian.

2. Risiko tertunda seperti penyakit tromboemboli, rasa sakit pasca operasi, dan hernia.

3. Risiko di kehamilan mendatang seperti plasentasi abnormal, bekas luka, kemandulan, keguguran, kehamilan ektopik, dan keharusan melakukan operasi sesar lagi

Menurut Soto-Vega dkk. (2015), angka persalinan sesar diatas 15 persen menunjukkan indikasi prosedur persalinan sesar yang sebenarnya tidak diperlukan, hal ini sejalan dengan WHO pada tahun 1985 yang menetapkan angka persalinan sesar ideal suatu negara adalah 10 sampai 15 persen. Pada tahun 2015, WHO kembali mengemukakan bahwa angka persalinan sesar diatas 10 persen tidak memiliki hubungan dengan penurunan angka kematian ibu dan bayi. Hal ini sejalan dengan kondisi yang terjadi di Indonesia pada tahun 2002 sampai 2012, dimana ketika angka persalinan sesar naik mendekati 10 persen, angka kematian ibu dan bayi turun, tetapi pada tahun 2012 ketika angka persalinan sesar diatas 10 persen, angka kematian ibu naik.

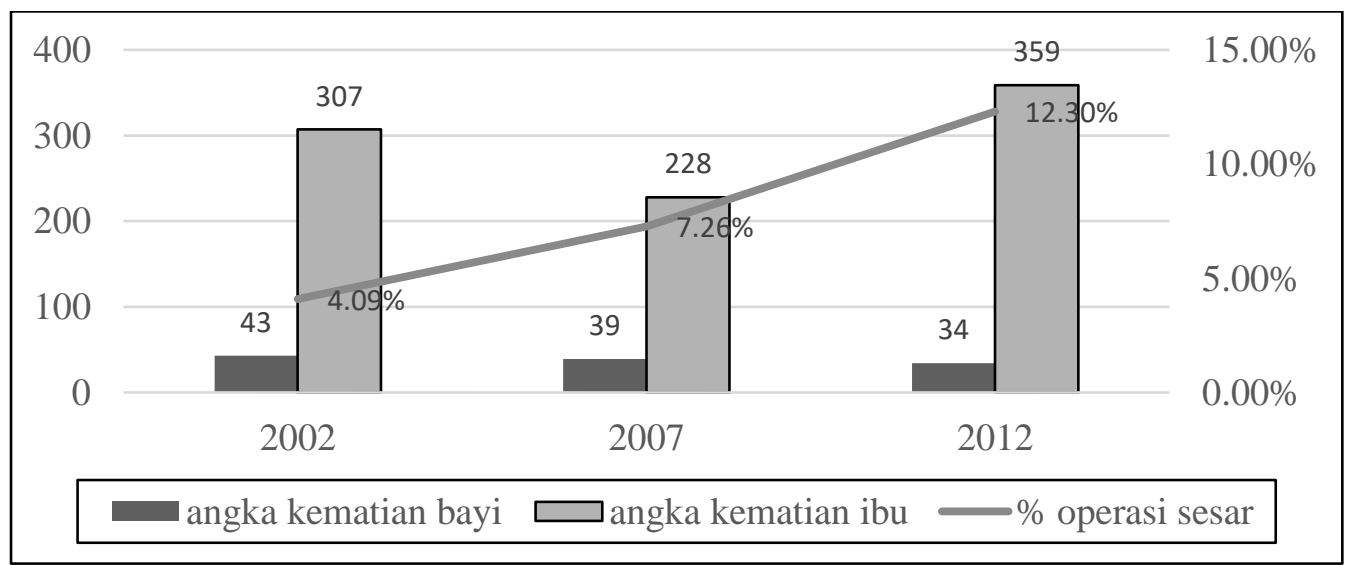

Sumber: BKKBN, BPS dan Kementerian Kesehatan(SDKI 2002, 2007, 2012)

Gambar 1. Angka persalinan sesar (persen), angka kematian ibu (per 100.000), dan angka kematian bayi Indonesia (per 1.000 kelahiran hidup) 2002-2012.

Persalinan sesar yang tidak terkontrol, terutama pada ibu tanpa komplikasi kehamilan akan meningkatkan risiko kematian ibu dan efek-efek sosial dan fisik yang tidak diinginkan bagi ibu 
(Majzoobi dkk., 2014). Ketika melakukan persalinan sesar, wanita meningkatkan risiko infeksi sebesar lima kali lipat dibanding persalinan normal (Villar dkk., 2007). Gilliam (2006) juga berpendapat bahwa wanita yang sebelumnya melakukan persalinan sesar akan mudah terpapar kehamilan ektopik dan aborsi spontan pada trimester pertama kehamilan. Tidak hanya ibu, bayi yang dilahirkan secara sesar juga memiliki risiko mengalami kelainan. Boitsikou (2011) mengemukakan efek-efek samping tersebut antara lain; masalah pernafasan, alergi, diabetes tipe I dan kanker. Menurut Publikasi Kementerian Kesehatan pada tahun 2013, didapatkan bahwa 30,3 persen dan 7,3 persen kematian ibu disebabkan oleh perdarahan dan infeksi yang merupakan efek samping dari operasi sesar. Persalinan sesar saat ini juga telah menjadi salah satu prosedur operasi yang paling umum dilakukan. Tren persalinan sesar mengalami kenaikan karena kemajuan metode bedah dan adanya persepsi keamanan dan keselamatan mengenai prosedur tersebut dimana yang memotivasi wanita untuk melakukan operasi sesar adalah karena takut akan persalinan normal dan menghindari rasa sakit (Soto-Vega dkk., 2015).

Dari hasil Survei Demografi dan Kesehatan Indonesia 2017, angka persalinan sesar Indonesia sebesar 17,02 persen. Namun, angka tersebut diikuti dengan tidak meratanya pemanfaatan persalinan sesar dimana sebesar 66,5 persen persalinan sesar dilakukan oleh wanita perkotaan dan sebesar 75 persen persalinan sesar dilakukan oleh wanita golongan menengah keatas. Hampir semua provinsi di Indonesia memiliki angka diatas 10 persen. Provinsi yang memiliki angka paling rendah adalah Maluku Utara, yaitu sebesar 6,2 persen sedangkan provinsi dengan angka tertinggi adalah Bali dengan angka 32,7 persen. Sedangkan bagi wanita tanpa komplikasi kehamilan, provinsi dengan angka persalinan sesar paling rendah adalah Nusa Tenggara Timur dengan angka 5 persen dan yang tertinggi adalah Bali dengan angka 34,7 persen. Hal ini Menunjukkan bahwa selain karakteristik individu, karakteristik wilayah juga berpengaruh terhadap keputusan persalinan sesar wanita tanpa komplikasi kehamilan.

Penelitian sebelumnya tentang determinan persalinan sesar menemukan beragam faktor yang berpengaruh. Dewanti (2010) dengan regresi logistik biner menemukan bahwa keputusan persalinan sesar dipengaruhi oleh status ekonomi, wilayah tempat tinggal, pendidikan, pekerjaan, penyakit persulit persalinan, komplikasi kehamilan, komplikasi persalinan, riwayat kelahiran hidup dan minimal empat kali pemeriksaan kehamilan. Sihombing, Saptriani dan Putri (2017) juga menemukan bahwa variabel yang memberikan pengaruh terhadap persalinan sesar adalah status sosial ekonomi, tingkat pendidikan, daerah tempat tinggal, status bekerja, kepemilikan jaminan kesehatan, usia kelahiran, jumlah janin, umur ibu, tinggi badan ibu, penyakit penyulit persalinan, komplikasi kehamilan, komplikasi persalinan, riwayat kelahiran hidup dan minimal empat kali pemeriksaan. Amini dkk. (2017) dengan menggunakan analisis multilevel menemukan bahwa Variabel independen yang signifikan yaitu status sosial ekonomi, indeks massa tubuh, paritas, jenis kehamilan, preeklampsia, ukuran janin, keliling kepala janin.

Analisis deskriptif penelitian ini akan menggunakan grafik untuk melihat gambaran umum dan karakteristik persalinan sesar wanita tanpa masalah kehamilan di Indonesia, sedangkan analisis inferensia penelitian ini akan menggunakan regresi logistik biner multilevel yang bertujuan untuk mengetahui variabel level individual dan kontekstual yang mempengaruhi keputusan persalinan sesar wanita tanpa komplikasi kehamilan. 


\section{METODE}

\section{Landasan Teori}

Menurut Mansjoer dkk. (2001), ada beberapa kondisi yang menyebabkan kehamilan menjadi tidak normal. Gejala yang menunjukkan kondisi tersebut antara lain; mual dan muntah berlebihan, pendarahan pervaginam, jantung berdebar, kelelahan otot, pembengkakan kelenjar tiroid, kejang atau koma, pucat atau syok, dan letak janin tidak normal.

Andersen (1975) dalam Andriani (2012) menjelaskan faktor-faktor yang mempengaruhi seseorang dalam memanfaatkan pelayanan kesehatan yang bernama The Initial Behavioral Model. Keputusan individu tergantung dari 3 faktor, yaitu faktor predisposisi yang terdiri oleh demografi, struktur sosial dan sikap individu. Faktor predisposisi yang dipakai dalam penelitian ini adalah usia wanita, daerah tempat tinggal, pendidikan yang ditamatkan, pekerjaan dan jumlah anak yang pernah dilahirkan. Faktor kedua yang mempengaruhi seorang dalam memanfaatkan pelayanan kesehatan adalah faktor pemungkin yang terdiri atas sumber daya keluarga dan sumber daya masyarakat. Faktor pemungkin yang dipakai dalam penelitian ini adalah indeks kekayaan, PDRB per kapita dan persentase rumah sakit swasta. Faktor terakhir yang mempengaruhi seorang dalam memanfaatkan pelayanan kesehatan adalah faktor kebutuhan, yang dapat dilihat dari laporan sendiri dari gejala yang dialami. Faktor kebutuhan yang dipakai dalam penelitian ini adalah riwayat keguguran dan keinginan hamil.

Usia berpengaruh signifikan terhadap persalinan sesar. Wanita berusia kurang dari 20 tahun dan 35 tahun keatas memiliki kecenderungan untuk bersalin sesar yang lebih besar dibanding wanita berusia 20 sampai 34 tahun (Khan dkk., 2017).

Wanita lulusan SLTA memiliki kecenderungan sebesar 2,86 kali lebih besar untuk melakukan operasi sesar dibanding wanita yang tidak tamat SLTA, sedangkan wanita yang menamatkan D3 atau perguruan tinggi memiliki kecenderungan sebesar 5,82 kali lebih besar untuk melakukan operasi sesar dibanding wanita yang tidak tamat SLTA (Sihombing, 2017). Wanita yang tidak bekerja lebih cenderung untuk melakukan operasi sesar dibanding wanita bekerja (Rahman dkk., 2018).

Wanita yang pernah melahirkan dua sampai empat anak memiliki kecenderungan 2,21 kali lebih besar untuk melakukan persalinan sesar dibanding wanita yang pernah melahirkan lima anak atau lebih, sedangkan wanita yang pertama kali melahirkan memiliki kecenderungan sebesar 2,96 kali lebih besar untuk melakukan operasi sesar dibanding wanita yang pernah melahirkan lima anak atau lebih.

Wanita yang pernah mengalami keguguran memiliki kecenderungan 3,89 kali lebih besar untuk bersalin secara sesar meskipun wanita tersebut tidak memiliki komplikasi kehamilan (Patel, 2005), sedangkan wanita yang tidak menginginkan kehamilannya 1,34 kali lebih cenderung untuk melakukan persalinan sesar dibanding wanita yang menginginkan kehamilannya (Amini dkk., 2018).

Selain variabel-variabel level individu di atas, dalam penelitian ini juga terdapat variabel level provinsi yaitu PDRB per kapita, dan persentase rumah sakit swasta. Melipatgandakan pendapatan per kapita juga mampu meningkatkan angka persalinan sesar sebesar 33 persen (Lauer dkk., 2010). Vecino-Ortiz dkk. (2009) dalam penelitiannya menemukan koefisien regresi rumah sakit umum bernilai negatif, hal ini menunjukkan bahwa dalam menangani persalinan wanita, rumah sakit umum lebih jarang melakukan prosedur persalinan sesar dibanding rumah sakit swasta. 


\section{Cakupan Penelitian}

Data dari penelitian ini berjenis sekunder yang berasal dari data mentah SDKI 2017 modul wanita usia subur. Selain itu, penelitian ini juga menggunakan variabel level wilayah PDRB per kapita tahun 2017 yang dipublikasikan oleh Badan Pusat Statistik. Variabel persentase rumah sakit swasta diperoleh dari profil kesehatan Indonesia 2017 yang dipublikasikan Kementerian Kesehatan dengan sedikit dilakukan pengolahan.

Penelitian ini menggunakan unit analisis penelitian ini adalah wanita yang tidak mengalami komplikasi kehamilan yang melahirkan selama periode survei. Rincian variabel yang digunakan adalah:

Tabel 1. Rincian variabel dan kategorinya

\begin{tabular}{|c|c|c|}
\hline Variabel & Nama Variabel & Keterangan \\
\hline (1) & (2) & (3) \\
\hline \multirow{2}{*}{ Variabel dependen } & \multirow{2}{*}{ Metode persalinan terakhir } & 0. Persalinan normal \\
\hline & & 1. Persalinan sesar \\
\hline \multirow{14}{*}{ Variabel individu } & \multirow{2}{*}{ Usia $\left(X_{1}\right)$} & $0 .<20>34$ \\
\hline & & 1. 20-34 (referensi) \\
\hline & \multirow{3}{*}{ Pendidikan terakhir $\left(\mathrm{X}_{2}\right)$} & 0. Tidak tamat SLTA (referensi) \\
\hline & & 1. Tamat SLTA \\
\hline & & 2. Perguruan tinggi \\
\hline & \multirow{2}{*}{ Pekerjaan wanita $\left(X_{3}\right)$} & 0. Tidak bekerja (referensi) \\
\hline & & 1. Bekerja \\
\hline & \multirow{2}{*}{ Riwayat keguguran $\left(\mathrm{X}_{4}\right)$} & 0. Tidak pernah (referensi) \\
\hline & & 1. Pernah \\
\hline & \multirow{2}{*}{ Keinginan hamil $\left(X_{5}\right)$} & 0. Tidak ingin \\
\hline & & 1. Ingin (referensi) \\
\hline & \multirow{3}{*}{ Anak yang pernah dilahirkan $\left(X_{6}\right)$} & 0.1 \\
\hline & & 1. $2-4$ \\
\hline & & 1. $>=5$ (referensi) \\
\hline \multirow{2}{*}{ Variabel wilayah } & PDRB per kapita ribu rupiah juta $\left(Z_{1}\right)$ & Numerik \\
\hline & Persentase Rumah Sakit Swasta $\left(\mathrm{Z}_{2}\right)$ & Numerik \\
\hline
\end{tabular}

\section{Metode Analisis}

Metode analisis yang dipakai adalah analisis deskriptif berupa tabel, peta dan grafik dan analisis inferensia regresi logistik biner multilevel, sedangkan software yang digunakan adalah Microsoft Excel 2013 dan STATA 14.

Dalam penelitian multilevel, terdapat dua model yang dibentuk yaitu:

1. Null Model

Model ini tidak mengandung variabel bebas sebagai model dasar yang akan dibandingkan dengan model yang lebih rumit. Dari model ini dapat diperoleh 
intraclass correlation coeficient (ICC) yang akan menunjukkan berapa persen keragaman variabel dependen yang disebabkan oleh karakteristik wilayah.

2. Conditional Model

Model ini mengandung variabel penjelas level satu dan dua. Model multilevel dibagi menjadi dua jenis yaitu:

1. Random Intercept Model

Pada model ini, terdapat asumsi bahwa masing-masing kelompok memiliki slope yang sama dan intercept yang berbeda. Hal ini membuat pengaruh setiap variabel independen sama di masing-masing wilayah. Model dari random intercept model:

$$
\operatorname{logit}\left(\pi_{i j}\right)=\ln \left(\frac{1}{1-\pi_{i j}}\right)=\beta_{0 j}+\beta_{1} \mathrm{X}_{i j 1}+\beta_{2} \mathrm{X}_{i j 2}+\cdots+\beta_{p} \mathrm{X}_{i j p}
$$

2. Random Slope Model

Kebalikan dari random intercept model, model ini mengasumsikan adanya perbedaan slope antar kelompok namun intercept pada masing-masing kelompok sama sehingga variabel independen memiliki pengaruh yang berbeda pada masing-masing wilayah. Model dari random slope model:

$$
\operatorname{logit}\left(\pi_{i j}\right)=\ln \left(\frac{1}{1-\pi_{i j}}\right)=\beta_{0}+\beta_{1 j} \mathrm{X}_{i j 1}+\beta_{2 j} \mathrm{X}_{i j 2}+\cdots+\beta_{p j} \mathrm{X}_{i j p}
$$

Penelitian ini akan menggunakan random intercept model dengan harapan variasi antar individu pada level provinsi terhadap pemilihan keputusan persalinan sesar dapat diketahui.

Untuk mendapatkan random intercept model ini, terdapat beberapa tahap yang perlu dilakukan. Yang pertama adalah dengan melakukan uji signifikansi random effect atau efek yang disebabkan variasi antar wilayah. Jika dari uji tersebut random effect tidak signifikan, maka regresi logistik biasa sudah cukup, namun bila signifikan tahap selanjutnya yang dilakukan adalah mencari ICC. Setelah ICC didapatkan, langkah selanjutnya adalah menguji variabel-variabel secara bersamaan dan secara parsial. Terakhir, dari variabel yang signifikan dicari odds ratio dengan cara mengeksponensialkan koefisien regresi sehingga diperoleh suatu nilai kecenderungan terjadinya kejadian pada variabel dependen.

Model regresi logistik biner multilevel yang dipakai adalah:

$\ln \left(\frac{\pi_{i j}}{1-\pi_{i j}}\right)=\gamma_{00}+\gamma_{10} X_{1 i j}+\gamma_{20} X_{2 i j}+\gamma_{30} X_{3 i j}+\gamma_{40} X_{4 i j}+\gamma_{50} X_{5 i j}+\gamma_{60} X_{6 i j}+\gamma_{01} Z_{1 j}+\gamma_{02} Z_{2 j}+\varepsilon_{i j}+$ $u_{j}$

Dimana:

Usia

Pekerjaan wanita

Keinginan hamil

PDRB per kapita

$\begin{array}{lll}=\mathrm{X}_{1} & \text { Pendidikan terakhir } & =\mathrm{X}_{2} \\ =\mathrm{X}_{3} & \text { Riwayat keguguran } & =\mathrm{X}_{4} \\ =\mathrm{X}_{5} & \text { Anak pernah lahir } & =\mathrm{X}_{6} \\ =\mathrm{Z}_{1} & \text { Persentase RS swasta } & =\mathrm{Z}_{2}\end{array}$

$$
\begin{gathered}
\varepsilon_{i j}=\text { residual individu ke }-\mathrm{i} \text { dalam wilayah } \mathrm{j} \\
u_{j}=\text { random effect } \text { wilayah } \mathrm{j}
\end{gathered}
$$

\section{HASIL DAN PEMBAHASAN}

Dari 8,255 kelahiran oleh wanita tanpa komplikasi kehamilan, 13,8 persen merupakan persalinan sesar, angka ini tidak sesuai dengan pernyataan 10 persen yang dikemukaan oleh WHO. Distribusi persalinan sesar menurut provinsi menunjukkan bahwa provinsi dengan angka persalinan 
sesar wanita tanpa komplikasi kehamilan tertinggi adalah Bali, DKI Jakarta dan DI Kepulauan Riau dengan angka masing-masing 34,7 persen, 30,3 persen dan 29 persen. Sementara provinsi dengan angka paling rendah adalah Nusa Tenggara Timur, Maluku dan Maluku Utara dengan angka masingmasing 5 persen, 5,9 persen dan 6,8 persen. Gambaran persalinan sesar menurut karakteristik individu bisa dilihat pada Tabel 2.

Tabel 2. Karakteristik individu

\begin{tabular}{|c|l|r|r|}
\hline \multirow{2}{*}{ Variabel } & \multicolumn{1}{|c|}{ kategori } & \multicolumn{2}{c|}{ Persalinan } \\
\cline { 2 - 4 } & & \multicolumn{1}{c|}{ sesar } & normal \\
\hline \multirow{3}{*}{ usia } & \multicolumn{1}{|c|}{2} & 3 & 4 \\
\hline \multirow{3}{*}{ pendidikan } & $\begin{array}{l}\text { kurang dari 20 tahun, lebih dari 34 } \\
\text { tahun }\end{array}$ & $16,00 \%$ & $84,00 \%$ \\
\cline { 2 - 4 } & 20 tahun sampai 34 tahun & $12,60 \%$ & $87,40 \%$ \\
\hline \multirow{2}{*}{ kegiatan } & $<$ SLTA & $9,00 \%$ & $91,00 \%$ \\
\cline { 2 - 4 } & tamat SLTA & $19,40 \%$ & $80,60 \%$ \\
\cline { 2 - 4 } & PT & $27,40 \%$ & $72,60 \%$ \\
\hline \multirow{2}{*}{ riwayat keguguran } & Bekerja & $14,50 \%$ & $85,50 \%$ \\
\cline { 2 - 4 } & tidak bekerja & $13,20 \%$ & $86,80 \%$ \\
\hline \multirow{2}{*}{ keinginan hamil } & tidak pernah & $13,20 \%$ & $86,80 \%$ \\
\cline { 2 - 4 } & Pernah & $17,60 \%$ & $82,40 \%$ \\
\hline \multirow{3}{*}{ anak yang pernah dilahirkan } & Ingin & $13,80 \%$ & $86,20 \%$ \\
\cline { 2 - 4 } & tidak ingin & $13,90 \%$ & $86,10 \%$ \\
\cline { 2 - 4 } & anak pertama & $16,80 \%$ & $83,20 \%$ \\
\cline { 2 - 4 } & 2 sampai 4 & $13,90 \%$ & $86,10 \%$ \\
\cline { 2 - 4 } & 5 atau lebih & $7,80 \%$ & $92,20 \%$ \\
\hline
\end{tabular}

Provinsi dengan PDRB per kapita paling tinggi adalah DKI Jakarta sebesar Rp 2.323.422.800 dengan persentase persalinan sesar 30,3 persen. Sementara provinsi dengan PDRB per kapita terendah adalah Nusa Tenggara Timur sebesar Rp 172.412.600 dengan persentase persalinan sesar 5 persen. Persentase rumah sakit swasta paling tinggi terdapat di provinsi Banten sebesar 86,25 persen dengan angka persalinan sesar sebesar 11,2 persen. Sedangkan persentase rumah sakit swasta paling rendah berada pada provinsi Kalimantan Tengah sebesar 10,6 persen dengan angka persalinan sesar 10,4 persen. Karakteristik masing-masing provinsi ditampilkan pada Tabel 3. 
Tabel 3. karakteristik wilayah

\begin{tabular}{|c|c|c|c|}
\hline Provinsi & $\begin{array}{c}\text { Persalinan sesar wanita tanpa } \\
\text { komplikasi }(\%)\end{array}$ & $\begin{array}{l}\text { PDRB per kapita (ribu) } \\
\text { harga berlaku }\end{array}$ & $\begin{array}{l}\text { Persentase RS } \\
\quad \text { swasta }\end{array}$ \\
\hline 1 & 2 & 3 & 7 \\
\hline Aceh & 19.1 & 28227,06 & 48,5714 \\
\hline Sumatera Utara & 19,6 & 47963,99 & 70,9091 \\
\hline Sumatera Barat & 21,6 & 40324,28 & 60,2564 \\
\hline Riau & 16,9 & 105990,99 & 63,8889 \\
\hline Jambi & 25,5 & 54366,37 & 54,2857 \\
\hline $\begin{array}{l}\text { Sumatera } \\
\text { Selatan }\end{array}$ & 12,3 & 46420,64 & 47,8261 \\
\hline Bengkulu & 16,7 & 31368,79 & 27,2727 \\
\hline Lampung & 16 & 37209,5 & 73,2394 \\
\hline $\begin{array}{l}\text { Kep. Bangka } \\
\text { Belitung }\end{array}$ & 14,2 & 48902,75 & 47,3684 \\
\hline Kep. Riau & 29 & 110310,55 & 54,8387 \\
\hline DKI Jakarta & 30,3 & 232342,28 & 68,7179 \\
\hline Jawa Barat & 14,2 & 37180,96 & 79,096 \\
\hline Jawa Tengah & 17,5 & 34650,4 & 73,9865 \\
\hline DI Yogyakarta & 28,1 & 31676,67 & 80,2469 \\
\hline Jawa Timur & 20,9 & 51388,32 & 71,7557 \\
\hline Banten & 11,2 & 45342,38 & 86,7925 \\
\hline Bali & 34,7 & 50714,59 & 69,8413 \\
\hline $\begin{array}{l}\text { Nusa Tenggara } \\
\text { Barat } \\
\end{array}$ & 11,6 & 25007,56 & 46,875 \\
\hline $\begin{array}{l}\text { Nusa Tenggara } \\
\text { Timur }\end{array}$ & 5 & 17241,26 & 41,6667 \\
\hline Kalimantan Barat & 8 & 35979,45 & 45,6522 \\
\hline $\begin{array}{l}\text { Kalimantan } \\
\text { Tengah }\end{array}$ & 10,4 & 48431,02 & 9,5238 \\
\hline $\begin{array}{l}\text { Kalimantan } \\
\text { Selatan }\end{array}$ & 9,8 & 38738,31 & 43,9024 \\
\hline $\begin{array}{l}\text { Kalimantan } \\
\text { Timur }\end{array}$ & 19,2 & 165714,16 & 54,5455 \\
\hline $\begin{array}{l}\text { Kalimantan } \\
\text { Utara }\end{array}$ & 11,1 & 112011,53 & 10 \\
\hline Sulawesi Utara & 13,6 & 44763,6 & 44,6809 \\
\hline Sulawesi Tengah & 11,7 & 45255,8 & 37,1429 \\
\hline Sulawesi Selatan & 13,2 & 48206,84 & 51 \\
\hline $\begin{array}{l}\text { Sulawesi } \\
\text { Tenggara }\end{array}$ & 7,3 & 41294,83 & 33,3333 \\
\hline Gorontalo & 17,2 & 29573,58 & 23,0769 \\
\hline Sulawesi Barat & 10,3 & 29766,44 & 33,3333 \\
\hline Maluku & 5,9 & 22857,7 & 25 \\
\hline Maluku Utara & 6,8 & 26686,06 & 22,7273 \\
\hline Papua Barat & 8 & 78426,5 & 12,5 \\
\hline Papua & 7,7 & 58684,09 & 19,0476 \\
\hline
\end{tabular}


Dari uji signifikansi random effect hasil STATA 14 (lampiran 1) diperoleh $p$-value 0.0000 . Dengan tingkat signifikansi sebesar 5 persen dan rasio likelihood sebesar $175,3>X_{(0,05 ; 1)}^{2}=3,84$ menghasilkan keputusan tolak H0. Dengan tingkat kepercayaan 95 persen, terdapat random effect yang signifikan sehingga regresi logistik multilevel dapat memberikan analisis yang lebih baik dibanding regresi logistik satu level. ICC yang didapatkan dari model dengan random effect tanpa variabel independen adalah 0,0752 yang berarti sebesar 7,52 persen variasi persalinan sesar disebabkan oleh perbedaan karakteristik wilayah. Kecenderungan dapat diperoleh dengan mengeksponensialkan koefisien regresi pada model.

Variabel yang mempengaruhi persalinan sesar wanita tanpa komplikasi kehamilan

$$
\begin{aligned}
\ln \left(\frac{\pi_{i j}}{1-\pi_{i j}}\right)= & -4,04^{*}+0,5494^{*} X_{1 i j}+0,7937^{*} X_{2 i j 1}+1,3889^{*} X_{2 i j 2}-0,059 X_{3 i j}+0,3806^{*} X_{4 i j} \\
& +0,0492 X_{5 i j}+0,7387^{*} X_{6 i j 0}+0,5304^{*} X_{8 i j 1}+0,004 Z_{1 j}+0,0147^{*} Z_{2 j}
\end{aligned}
$$

Dengan tanda $*$ menunjukkan variabel independen signifikan pada $a=0,05$

Wanita berusia kurang dari 20 tahun dan 35 tahun keatas memiliki kecenderungan sebesar 1,7322 kali lebih besar untuk melakukan persalinan sesar dibandingkan wanita berusia antara 20 sampai 34 tahun dengan asumsi variabel lain konstan. Hal ini wajar mengingat ibu hamil dibawah usia 20 tahun belum siap secara emosional dan mental, sementara wanita berusia 35 tahun keatas memiliki sel telur yang kehilangan kemampuan menghasilkan hormon estrogen dan progesteron sehingga rahim akan berkontraksi dan tidak optimal.

Wanita yang menamatkan SLTA memiliki kecenderungan sebesar 2,2115 kali lebih besar untuk melakukan operasi sesar daripada persalinan normal dibanding wanita yang tidak menamatkan SLTA. Selain itu, wanita yang menamatkan perguruan tinggi juga memiliki kecenderungan sebesar 4,0104 kali lebih besar untuk melakukan operasi sesar dibanding wanita yang tidak menamatkan SLTA dengan asumsi variabel lain konstan. Ibu yang memiliki tingkat pendidikan tinggi memiliki dorongan untuk mengawasi kehamilan dan persalinannya dibandingkan ibu berpendidikan rendah. Selain itu, wanita yang tidak menamatkan SLTA cenderung berada pada kategori miskin atau paling miskin yang menyebabkan mereka tidak memiliki sumber daya untuk melakukan operasi sesar. Semakin tinggi pendidikan wanita juga membuat wanita menjadi lebih berkuasa dalam memilih metode persalinan dan wanita yang berpendidikan juga cenderung berpendapat bahwa operasi sesar adalah metode yang aman dan tidak memakan waktu bekerja dan bersantai mereka.

Wanita yang pernah mengalami keguguran memiliki kecenderungan sebesar 1,4631 kali lebih besar untuk melakukan operasi sesar daripada persalinan normal dibanding wanita yang tidak pernah mengalami keguguran dengan asumsi variabel lain konstan. Riwayat keguguran menyebabkan wanita takut terhadap persalinan sehingga mereka lebih memilih persalinan sesar.

Wanita yang melahirkan anak pertama memiliki kecenderungan sebesar 2,0932 kali lebih besar untuk melakukan persalinan sesar daripada persalinan normal dibanding wanita pernah melahirkan 5 anak atau lebih dengan asumsi variabel lain konstan. Wanita yang pernah melahirkan 2 sampai 4 anak memiliki kecenderungan sebesar 1,6996 kali lebih besar untuk melakukan operasi dibanding persalinan normal daripada wanita yang pernah melahirkan 5 anak atau lebih dengan asumsi variabel lain konstan. Hal ini disebabkan karena wanita golongan menengah, kaya dan paling kaya cenderung tidak memiliki 5 anak atau lebih.

Variabel wilayah yang secara signifikan berpengaruh adalah PDRB per kapita (juta) dan persentase rumah sakit swasta. Kenaikan PDRB per kapita sebesar satu satuan (juta) akan meningkatkan kecenderungan persalinan sesar sebesar 1,004 kali di wilayah itu, sedangkan 
kenaikan persentase rumah sakit swasta sebesar 1 persen akan meningkatkan kecenderungan persalinan sesar sebesar 1,1587 kali di wilayah itu.

\section{KESIMPULAN}

Berdasarkan hasil penelitian yang telah dilakukan mengenai faktor-faktor yang mempengaruhi persalinan sesar pada wanita usia subur tanpa komplikasi kehamilan, ditemukan bahwa persalinan sesar yang dilakukan oleh wanita tanpa komplikasi kehamilan adalah sebesar 13,8 persen yang mana persalinan tersebut dipengaruhi oleh usia, pendidikan formal yang ditamatkan, riwayat keguguran, anak yang pernah dilahirkan dan karakteristik wilayah PDRB per kapita dan persentase rumah sakit swasta. Dari variabel-variabel tersebut, wanita lulusan perguruan tinggi memiliki koefisien regresi yang paling besar dibanding yang lain.

\section{UCAPAN TERIMA KASIH}

Ucapan terima kasih diberikan kepada BKKBN, BPS dan Kementerian Kesehatan selaku penyedia data.

\section{DAFTAR PUSTAKA}

Andriani, D (2012). Faktor-Faktor Yang Mempengaruhi Tindakan Seksio Sesarea di Rumah Sakit Umum Daerah Kabupaten Dompu Tahun 2010. Universitas Indonesia. Depok. $89 \mathrm{hlm}$.

Amini, P dkk (2018). Factors Associated With Caesarean Section in Tehran, Iran Using Multilevel Logistic Regression Model. Osong Public Health and Research Prespectives. 9(2), 86-92

Boutsikou, T dan Puchner, AM (2011). Caesarean Section: Impact on Mother and Child. Acta Paediactrica $100,1518-1522$.

Gilliam, M (2006). Caesarean Delivery on Request: Reproductive Consequences. Seminars in Perinatology.257260

Khan, MN dkk (2017). Socio-demographic Predictors and Average Annual Rates of Caesarean Section in Bangladesh Between 2004 and 2014. PloS ONE. 12(5).

Kementerian Kesehatan (2014). INFODATIN. Pusat Data dan Informasi. Diakses pada Oktober 2018 melalui http://www.depkes.go.id/resources/download/pusdatin/infodatin/infodatin-ibu.pdf

Lauer, JA dkk (2010). Determinants of Caesarean Section Rates in Developerd Countries: Supply, Demand and Opportunites for Control. Diakses pada Januari 2019 melalui https://www.who.int/healthsystems/topics/financing/healthreport/29DeterminantsC-section.pdf

Mansjoer, A dkk (2001). Kapita Selektia Kedokteran (edisi 3). Jakarta; Fakultas Kedokteran Universitas Indonesia

Patel, RR dkk (2005). Prenatal Risk Factors for CaesareanSection. Analyses of The ALSPAC Cohort of 12,944 Women in England. International Journal of Epidemiology. 34(2), 353-367.

Rahman, MM dkk (2018). Determinants of Caesarean Section in Bangladesh: Cross-sectional analysis of Bangladesh Demographic and Health Survey 2014 Data. PloS ONE, 13(9).

Sihombing, N dkk (2017). Determinan Persalinan Sectio Caesarea di Indonesia (Analisis Lanjut Data Riskesdas 2013). Jurnal Kesehatan Reproduksi, 63-75.

Soto-Vega, E dkk (2015). Rising Trends of Caesarean Section Worldwide :A Systematic Review. Obstetric and Gynecology International Journal. 3(2) 00073. 
Stalker, P disunting oleh Syebubakar et.al (2008). Millenium Development Goals. Diakses pada Oktober 2018 melalui https://www.undp.org/content/dam/indonesia/docs/MDG/Let\%20Speak\%200ut\%20for\%20MDGs\% 20-\%20ID.pdf

United Nations (2017). SDG Indicators. General Assembly. Diakses pada Oktober 2018 melalui https://unstats.un.org/sdgs/indicators/indicators-list/

Vecino-Ortiz, AI dkk (2015). Hospital Variation in Caesarean Delivery: A Multilevel Analysis. Value in Health Regional Issues. 8C. 116-121.

Villar, J dkk (2007). Maternal and Neonatal Individual Risks and Benefits Associated With Caesarean Delivery: Multicentre Prospective Study. BMJ.335,1025

WHO (2015). WHO Statements on Caesarean Section Rates. Diakses pada Oktober 2018 melalui https://www.who.int/reproductivehealth/publications/maternal perinatal health/cs-statement/en/

\section{LAMPIRAN}

Lampiran 1, null mode/ dengan random effect

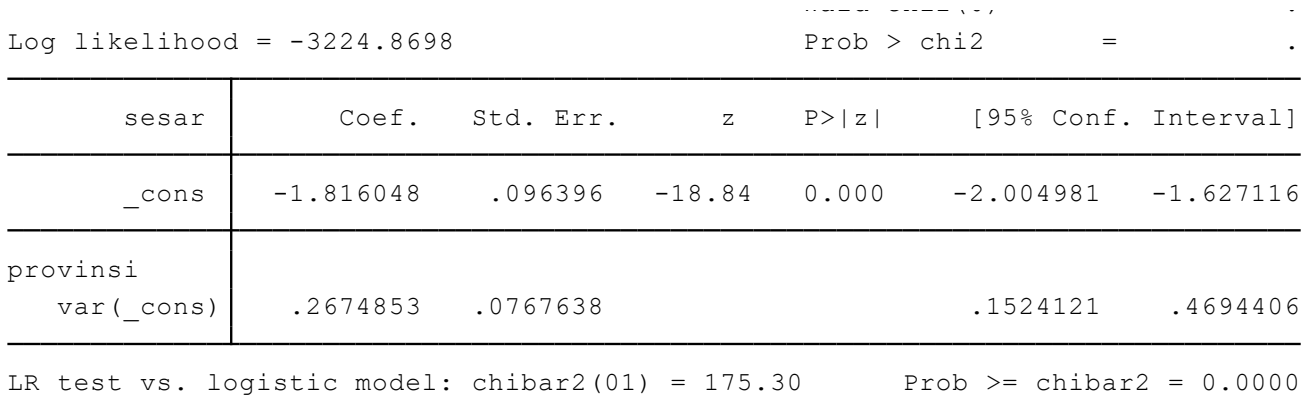

Lampiran 2, full mode/dengan random effect

\begin{tabular}{|c|c|c|c|}
\hline Mixed-effects logistic regression & Number of obs & $=$ & 8,251 \\
\hline \multirow[t]{5}{*}{ Group variable: } & Number of groups & $=$ & 34 \\
\hline & Obs per group: & & \\
\hline & $\min$ & $=$ & 49 \\
\hline & $\operatorname{avg}$ & $=$ & 242.7 \\
\hline & $\max$ & $=$ & 662 \\
\hline \multirow[t]{2}{*}{ Integration method: mvaghermite } & Integration pts. & $=$ & 7 \\
\hline & Wald chi2(10) & $=$ & 360.00 \\
\hline Log likelihood $=-3059.8766$ & Prob > chi2 & $=$ & 0.0000 \\
\hline
\end{tabular}


Seminar Nasional Official Statistics 2019: Pengembangan Official Statistics dalam mendukung Implementasi SDG's

\begin{tabular}{|c|c|c|c|c|c|c|}
\hline sesar & Coef. & Std. Err. & z & $P>|z|$ & [95\% Conf. & Interval] \\
\hline pdrb_kab_juta & .0040446 & .0013357 & 3.03 & 0.002 & .0014266 & .0066625 \\
\hline prop_swasta & .0147391 & .0029044 & 5.07 & 0.000 & .0090465 & .0204317 \\
\hline usia & & & & & & \\
\hline$<20>34$ & .5494153 & .0739496 & 7.43 & 0.000 & .4044767 & .6943538 \\
\hline \multicolumn{7}{|l|}{ pendidikan } \\
\hline tamat SLTA & .7937422 & .0765393 & 10.37 & 0.000 & .643728 & .9437564 \\
\hline Pergururan tinggi & 1.388948 & .095917 & 14.48 & 0.000 & 1.200954 & 1.576942 \\
\hline \multicolumn{7}{|l|}{ pekerjaan } \\
\hline bekerja & -.059007 & .0689223 & -0.86 & 0.392 & -.1940924 & .0760783 \\
\hline 9 & 0 & $(e m p t y)$ & & & & \\
\hline \multicolumn{7}{|l|}{ riwayat_keguguran } \\
\hline pernah & .3806359 & .0903443 & 4.21 & 0.000 & .2035643 & .5577075 \\
\hline \multicolumn{7}{|l|}{ keinginan_hamil } \\
\hline ingin & .0492144 & .0867093 & 0.57 & 0.570 & -.1207327 & .2191616 \\
\hline \multicolumn{7}{|l|}{ anak_pernah_dilahirkan } \\
\hline 1 & .7387138 & .1489382 & 4.96 & 0.000 & .4468003 & 1.030627 \\
\hline 2 sampai 4 & .5304024 & .1322227 & 4.01 & 0.000 & .2712507 & .7895542 \\
\hline _cons & -4.040551 & .2222354 & -18.18 & 0.000 & -4.476125 & -3.604978 \\
\hline \multicolumn{7}{|l|}{ provinsi } \\
\hline $\operatorname{var}($ _cons $)$ & .0710147 & .0275716 & & & .0331793 & .151995 \\
\hline
\end{tabular}

LR test vs. logistic model: chibar2 $(01)=33.88 \quad$ Prob $>=$ chibar2 $=0.0000$ 